\title{
Remaking Public Participation: The Case of Singapore
}

\author{
Abdillah Noh (Corresponding Author) \\ Department of Administrative Studies and Politics \\ Faculty of Economics and Administration \\ University of Malaya \\ 50603 Kuala Lumpur, Malaysia \\ Tel:+603-79673697_E-mail: abdillah@um.edu.my \\ Makmor Tumin \\ Department of Administrative Studies and Politics \\ Faculty of Economics and Administration \\ University of Malaya \\ 50603 Kuala Lumpur, Malaysia \\ Tel: +603-79673690Ｅ-mail: makmor@um.edu.my
}

\begin{abstract}
This paper discusses public participation or active citizenship embodied in the Remaking of Singapore and Singapore 21 documents. It looks at the extent public participation has been incorporated in two of Singapore's latest policy initiatives; the Integrated Resort and the Increase in Ministerial pay. The paper highlights that participation in Singapore, is "pseudo" or "partial" in character. It is guided by existing authoritarian structures and prevailing societal norms; structures and norms that have been shaped by years of Peoples' Action Party (PAP) led involvement in the economic, political and social spheres. Under such circumstances, efforts at active citizenship and public participation would at best be gradual; an exercise that is highly contingent on the dynamic accommodation of state authority structures with that of the larger society.
\end{abstract}

Keywords: Public participation, Remaking, Policy initiatives, Authoritarian structures, Prevailing societal norms.

\section{Introduction}

Singapore's transformation from an economic backwater to a thriving nation needs little introduction. For the last forty odd years, it has raked in accolades and has continued to defy critics; critics that questioned the ability of a $647 \mathrm{sq} \mathrm{km}$ city state with no natural resources to survive let alone become one of world's success stories. There is no short of views in describing Singapore's development and leadership. Austin (2001) views strong governance with high doses of pragmatism on the part of its leadership as key determinants of Singapore transformation (Austin, 2001). The state was pragmatic in its choice of development policy, the bureaucracy was fully socialized into developmentalist values, and the public acquiesced for the sake of this national vision and project (Koh, 1998). Chan (1975) describes Singapore as an administrative state whose leadership's immediate preoccupation post independence was about employment and maintaining or improving, political, social conditions. Mauzy \& Milne (2002) view the state and its leadership as authoritarian in nature arguing that although Singapore has most of the trappings of democracy - parliamentary system of government, elected president, universal suffrage and regular and free election, certain draconian laws, controls on political participation, and measures limiting civil and political rights and freedom of the press, mean that Singapore is, to some extent, an authoritarian state.

Since the late 80 s and especially after the hand over of leadership from the old to the new guards, Singapore leadership has been attempting to take a "softer" approach - a more participatory approach - when it comes to decision making. Shifting societal expectations and changing political economy has prompted its leaders to regard participation as an important ingredient in the new Singapore. This paper however view that a more participatory Singapore, is still at a nascent stage. Taking cue from various conceptual frameworks, the paper will highlight that the participatory posture of the Singapore leadership needs constant retooling, one where existing authoritarian structures and norms of the ruling elite need to take into account shifting acceptance level of acceptance of authority of the larger society. 
The paper is organized as follows. The second part of the paper will provide the theoretical framework on participation. The next section will highlight the rationale for Singapore in promoting a more participatory environment and the mechanism used to promote it. The fourth part paper of the paper will briefly describe two documents - Singapore 21 and the Remaking of Singapore - documents that attempt to create a greater level of participation as well as encouraging a more inclusive society. The fifth and sixth part of the paper will discuss how the terms embodied in the two documents are actuated with two recent policy issues; the ministerial pay hike and the Integrated Resort. The final part will provide the analysis.

\section{The Literature Review}

Participation with regards to policy making process is getting renewed interest for obvious reasons; the presence of a perceived democratic deficit, to enhance the legitimacy of decision making, improve public delivery system and to allow citizens, especially the disadvantaged and marginalized to have their say in issues affecting them (Barnes, Marian, Newman J, Sullivan H., 2004).

Participation is a loaded term with social scientists preferring to make inferences by associating the term with efforts at ensuring good government, protecting private interest and improving decision making. Rousseau in his seminal work, The Social Contract makes the point that participation allows the development of man's "faculties" (Rousseau 1968) Rousseau. He articulates that participation encourages a moral condition when man relegates his own interests and inclinations to that of the common will.

The passage from the state of nature to the civil state produces a very remarkable change in man, by substituting justice for instincts in his conduct and giving his actions the morality they had formerly lacked. Then only, when the voice of duty takes the place of physical impulses and right of appetite, does man, who so far had considered only himself, find that he is forced to act on different principles, and to consult his reasons before listening to his inclinations (Rousseau, 1968).

John Stuart Mill advocates political pluralism on grounds that it provides an educative function and in turning citizens to become public oriented citizens (see Mill 1964). Mills believes that that the political machinery should be worked by men not through simple acquiescence but through active citizenship (Mill, J.S., 1964). Active citizenship promotes integration, one where the citizens feel that they are part of wider community. Active citizenship or participation also ensures good government, in which public decisions would provide for better implementation of policies. Despite advocating public participation, Mills however believes in unequal voting, where more votes should be given to the educated and wise and that active participation "must be adjusted to the capacities and qualities of such men as are available" (Mill, J.S., 1951).

It is in the area of management that the term participation is given more specificity. Mcgregor (1960) defines participation as one where opportunities are created for people to influence decisions affecting them.

... (participation) is a special case of delegation in which subordinates gain greater control, greater freedom of choice, with respect to his own responsibilities. The term participation is usually applied to the subordinate's greater influence over matters within the superior's responsibilities (Mcgregor, D., 1960).

When discussing participation one obvious question to ask is whether it leads to better government and better citizens. Mills (1964) for instance touches on the educative element of participation and how it leads to better government. Mansfield (1995) persuasively argues that it is obvious that participation makes better citizens, but somehow "you cannot prove it even when everyone believes in it". She elaborates that even when early writers on democracy and participation did not explicitly point out that participation naturally leads to better citizens there are inferences to suggest that participation enhances citizens and societal interests. In reiterating this point Mansfield, lends her argument from the Aristotelian view that "man is by nature an animal intended to live in a polis and that the end, or goal, of the state is to "ensure a proper quality of character among the members (and) that it shall be free from injustice and form of vice”, that implicitly suggests man's natural inclination for social relationship and to partake in state's decision making process in achieving a common good.

Another important issue when discussing participation is the debate on the best form of participation - that of direct participation versus representative government. Arguments on direct participation draw references from the classical theory of democracy that adopts a utilitarian approach and one that is based on individual rational choices. Rousseau (1968) adopts the utilitarian perspective pointing out that allowing participation would ensure that citizens are turned into public citizens - a condition that encourages them to look beyond self interest and seek for a common good. However, theories relating to representative government, argues that a government for the people would be a more feasible option than the classical theory's approach of government by the people. This view adopts limited public involvement in the political decision making, one that is mainly carried out through electoral voting. Perhaps one of the important thoughts on this comes from Joseph Schumpheter' (1942) work on Capitalism, Socialism and Democracy. Here, Shumpeter reinterpretes democracy "as just type of institutional arrangement for arriving at political-legislative 
and administrative - decisions and hence incapable of being an end in itself". Schumpeter argues that "democracy does not mean and cannot mean that the people actually rule in any obvious sense of the term 'people' and 'rule'. He argues that even if the common will might come up from a "jumble"of individual actions or volitions, the end results would be that the "Will" will no longer be congruent with any "good". In his words

Even if the opinions and desires of individual citizens were perfectly definite... and if everyone acted on them with ideal rationality and promptitude, it would not necessarily follow that the political decisions produced by that process...would represent anything that could in any convincing sense be called the will of the people... whenever individual wills are much divided, very likely that the political decisions produced will not conform to "what people really want"...Nor can it be replied that, if not exactly what they want, they will get a "fair compromise" (Schumpeter, 1942: 225).

Schumpeter believes that participation should be in the form of representation through democratically appointed leaders. He points out that leaders acquire power by means of a competitive struggle for people's vote, so it is natural that representation of opinion and hence participation will come from leaders who are competitively elected through the democratic process.

Later works on participation drew inspiration from Schumpeter's work. Eckstein (1966) for instance raises some provoking and rather interesting proposition on participation and authority. Eckstein ties the idea of democratic stability and participation with the authority structure present within a polity. He believes that "a government will tend to be stable if its authority pattern is congruent with the other authority patterns of the society of which it is part." Eckstein points out that men psychologically have a need for firm(authoritarian) leaders and this must be satisfied if the stability of the system is to be maintained (Pateman, 1970:13). He argues that effective decision making can only take place if the element of authoritarianism is present.

Eckstein added an interesting proposition to his arguments stating that his thesis is not about legitimizing boundless authoritarian imposition by leaders but an authoritative form in so far as citizens would find acceptable. And the "acceptable" authoritative form depends on the society socialization process viz schools, families, non governmental social relationship. In Eckstein words:

...if any aspect of social life can directly affect government it is the experiences with authority that men have in other spheres of life, especially those that mould their personalities and those to which they normally devote most of their lives (Eckstein, 1996).

Eckstein also makes the point that participation and authoritarianism must exist within a stable democracy, a condition where elections decide the outcome of competition for policies and power. Ironically, for stable democracy to exist Eckstein believes that governmental pattern must not be 'purely' democratic as it must contain a "balance of disparate elements" and there must be a "healthy element of authoritarianism" (Pateman, 1970:13). Eckstein work on democracy and participation with its heavy inferences on authority structures raises interesting considerations, especially when one discusses the case of Singapore and perhaps many other East Asian countries - states that are highly associated with authoritarian brand of leadership operated under democratic institutions.

Besides Eckstein there are other works that test the premise of the classical theory of democracy and participation. Berelson (1952: 6) also argues against the utilitarian posture of the classical theory, pointing out that the "classical"theory concentrates on the individual citizen and virtually ignores the political system, which is about limiting conflict, restraining the rate of change, maintaining economic and social stability, creating a pluralistic social organization and having basic consensus. In pointing out the significance of representative government, Berelson stresses the point that "the individual members may not meet all the standards, but the whole nevertheless survives and grows."

Along somewhat similar lines, Dahl's (1956) Preface to Democratic Theory promotes an elitist idea that democracy is polyarchist in nature - a rule of multiple minorities. Dahl takes on the premise that the majority of citizens tend to be disinterested and apathetic about politics and that only a small proportion of individuals in any form of social organization will take up decision making.

Dahl's mentions that for democratic rule by polyarchist to work, there need to be a consensus of what is acceptable, at least among the leaders. He goes on to explain that how successful the democratic arrangement will be really depends on the socialization process of its leaders - a process that is obtained through the family, schools, media etc. Presumably, "effective" social training would be training that develops individual attitudes that support the democratic norms. To further the idea on representative government, Dahl underlines the point that "political equality" must be not be misconstrued as "equality of political control or power" as the majority are politically inactive and have limited access to resource". In fact, Dahl cautions that allowing an increase in participation would undermine the stability of the democratic system, arguing on the grounds that lower socio economic groups consists of "inherent "authoritarian" personalities who would upset existing values of the democratic system. 
Dahl believes that polyarchist rule by the minority will not undermine democracy, as the democratic process will provide the necessary checks on the ruling minorities. This is done through the electoral process where leaders need to compete to secure the votes of the people. Despite, Dahl's assuredness, it must also be added that the electoral process can be "secured" by the ruling minority through the application of various state's mechanism and structures, all in an attempt to ensure that the electoral mechanism would be highly favourable to the ruling minority.

\subsection{Participation: Power, Influence and Its Different Genres}

When discussing participation in the democratic process, the term cannot be divorced from the adjectives "power" and "influence". Barnes, Newman and Sullivan (2004) view participation as one that is guided by strong political and organizational norms and the resilience of "frameworks of power". In their study, on public participation on communities in two English cities, Barnes, Newman and Sullivan found out that citizens' engagement is subjected to the resilience of old institutional norms and rules and the importance of strong social networks. These factors influence ultimate policy and oftentimes resulted in the occasional "fobbing off" - a situation where public organization failed to respond to citizens' concerns. The work by Barnes, Newman and Sullivan has an important bearing on state's disposition to participation because as much as a state's leadership wants to espouse a higher degree of participation, such an exercise is highly contingent on preexisting institutional norms and rules. These norms and structures could potentially be insidious in character but have great influence in determining the texture of a policy outcome.

Taking discussion further, the ability to appreciate the interplay between power, influence and existing norms could help us better understand the various participatory situations that states exhibit. Pateman (1970: 69) for instance provides three different types of participation that typifies states' effort at active citizenship. To understand the three types of participation Pateman emphasizes the importance of making a distinction between power and influence where she describes that "to be in a position to influence a decision is not the same thing as to be in a position (to have the power to) to determine the outcome or to make that decision. Based on such distinction and lending her arguments heavily on Verba's (1961) work on participation, Pateman describes lucidly three levels of participation; pseudo participation, partial participation and full participation. This is discussed below.

\subsubsection{Pseudo Participation}

Pseudo participation refers to a situation where the concern is not about creating an environment where decisions are finally made, but rather to create a feeling of participation. Leaders have a particular goal in mind and thus adopt a particular approach to induce acceptance of the predetermined goal. (Note 1) It is a cover technique meant to increase efficiency and to persuade (employees) to accept decisions already made by the management (Pateman, 1970: 68).

\subsubsection{Partial Participation}

This involves "a process in which two or more parties influence each other in the making of decisions but the final power to decide rests with one party only" (Pateman, 1970: 70). It leverages on the distinction between power and influence where Pateman describes that workers are in a permanent subordinate position unable to exercise power but can only influence the final outcome.

\subsubsection{Full Participation}

This is an ideal situation among equals "where each individual member of a decision making-body has equal power to determine the outcome of decisions" (Pateman, 1970:70). Drawing the example of an industrial workplace, Pateman describes full participation as a condition where no "two" sides have unequal decision making power, and that group of individuals make their own decisions and how to allocate and implement work.

Pateman's description of the different types of participatory situations plus earlier discussions on authority, power and influence provide important references in appraising Singapore's recent move towards a more participative and inclusive society and the attendant challenges; issues that the following sections attempt to discuss.

\section{The Need for a More Consultative Style}

Since the mid eighties there is a gradual shift by Singapore's ruling PAP led government to bring about a more inclusive and participatory style of leadership, a sharp contrast to the authoritarian posture seen during Singapore's early years after independence. Growing sophistication of the Singaporean society has brought about differentiated social and political values. More than just wanting a well functioning economy, Singapore's middle class, especially the young and educated, increasingly demand greater political space and a more participatory environment. Election results since the 1980s, has indicated such changing societal expectations. During Singapore's last general election in 2006, the internet was filled with satirical pod cast, video clips of election rally and blogsites discussing political strategies used by the political parties in the run up to polling day. Local blogsites www.singaporegovt.blogspot.com received some 5 000 to 6000 hits during the nine-day campaign, double what it normally gets. (Note 2) Perhaps public opinion on cyberspace during the run up to polling day could have been more, if not for the Singapore government's warning that individual websites and blogsites, that persistently promote the position of a political party must be registered, failing 
which such blogsites would be barred from running election-related news or risk being fine. (Note 3) Though it may be difficult to ascertain voting patterns and the reasons for the drop in majority votes for the PAP during the last 2006 elections (Note 4), judging from the fervour during the run up to polling day and large turnouts at opposition party's rally, it may not be too presumptuous to make the supposition that one cannot discount that Singapore voters, perhaps especially younger voters, would like greater latitude and tolerance for political pluralism and participation. Changing expectation, especially amongst younger voters, was evident during the last general election in 2006 where during an open discussion with Singapore then Senior Minister Lee Kuan Yew, young Singaporeans indicated their desire for the ruling PAP government to soften its stance on the opposition and for Singaporeans to be more involved in the running of the state. (Note 5)

In fact, increasing appetite for a more participative and pluralistic political representation was felt as far back in 1981, when the PAP lost a parliamentary seat in a by-election, marking the first time since 1968 that the PAP failed to obtain a monopoly of parliamentary seats. The trend continued in the 1984 general election, where its share of the votes slipped from a high of 75 percent during the 1980 election to 62.9 percent. Since then the PAP has failed to take all parliamentary seats. The poll results suggest, among other things, the growing need for an alternative voice in parliament, one where voters "do not want controversial policies that affect them to be formulated and implemented without taking their views and sentiments into account (Quah, 2000)."

Ever since the PAP lost the Anson seat in the 1981 by-election and the subsequent presence of opposition members in parliament, the PAP has come up with a number of ways to address Singaporeans growing need for opposing views or an alternative voice in parliament. As far back as 1985, the government formed the Feedback unit, now called Reach. Later, the government initiated the National Agenda, later renamed Agenda for Action which was adopted in 1988. (Note 6) Though the formation of the feedback unit and the initiation of the National Agenda were clear manifestations of the PAP government's desire to obtain more accurate feedback from Singaporeans about what they wanted as well as its commitment towards a more consultative style (Note 7), they were also clear efforts at addressing Singapore voters increasing disposition for an alternative voice in parliament. There were other instruments employed to address shifting expectations. Sensing public need for an opposition voice in parliament, the PAP led government introduced the Non-Constituency MP (NCMP) to allow three opposition candidates who had lost during the election but had received the highest percentage of electoral votes amongst the candidates who lost. This would allow parliament to have at least three opposition members, even if the PAP had won all parliamentary seats. However, the NCMPs will not been able to vote in parliament on any motion relating to a Bill to amend the Constitution, a Supply Bill or Supplementary Supply Bill, a Money Bill or a vote of no confidence in the government. (Note 8)Adding to the NCMP initiative, the state introduced the Nominated Member of Parliament (NMPs) in 1989 where initially up to six nominated members can be elected by parliament. This has been increased to nine. These NMPs will have the same rights as the NCMPs. The state's aim at introducing the NMP bill is "to further strengthen (the) political system by offering Singaporean's more opportunity for political participation and to evolve a more consensual style of government where alternative views are heard and constructive dissent accommodated. (Note 9) Most NMPs are professionals, working in think tanks, representing trade unions, non governmental organizations and those active in grassroot activities. To some it is obvious that, besides the move to accommodate citizens' increased propensity to be active in the policy making process, the initiatives were also meant to retain a virtual one party state and moves at "political co-option meant to obviate the need for more elected opposition MPs, or an independent civil society" (Rodan, 2006). And there were other important initiatives. In 1991, a white paper on "Shared values" was tabled effectively elevating it as a national ideology. The white paper addresses the lack of "common unique culture" among Singaporeans and highlights the need to identify with values that have a distinct Singaporean character, one that can hold Singaporeans together during times of crisis. (Note 10)Though the white paper did not tackle the increasing need for participation head on, it obliquely address the need for Singaporeans to share a common mission and one that is congruent to Singapore's and the PAP's past development philosophy.

Increasingly, through years of virtual single party state, economic success and attendant depoliticisation, the state has also created apathetic young Singaporeans with seeming lack of "rootedness" and receding sense of ownership. Despite the good life, more Singaporeans expressed hope of leaving. A survey conducted by Singapore's Straits Times in July 2006 found that two thirds of Singaporeans interviewed would like to work abroad and 53 percent of those surveyed would consider emigration, figures that are much higher when compared to their peers in India and Malaysia. (Note 11) As much as it wants to attract a transient international workforce, there is also the concern that Singapore might lose a critical mass of its own indigenous talents, a core of its best that the government feels could provide a bulwark to its development objectives.

In fact, Singapore second and third generation of leaders post - Lee Kuan Yew have made it a point to address the issue of participation and active citizenship as a top priority. Goh Chok Tong, when he took up position as Singapore's second prime minister declared his intention to embrace a more open, consultative, and consensual leadership (Lee, 2005). Lee Hsien Loong during his inaugural speech as prime minister reiterated this point saying that "our people 
should feel free to express diverse views, pursue unconventional ideas, or simply be different. We should have the confidence to engage in robust debate, so as to understand our problems, conceive fresh solutions, and open up new spaces. (Lee Hsien Loong, 2004). For some the pace, direction and manner in which participation are carried out remain debatable with some arguing that such statements are gestural in nature, meant to appease public desire for greater participation (Lee, 2005).

Besides the immediate need to placate a more sophisticated electorate, Singapore's leadership increasingly understand that a more consultative and participatory environment would provide a welcome inducement to the state's renewal efforts. Singapore leadership is bent on repositioning the city state, hoping to turn it into a must see global city and a magnet for the world's best and brightest. Though precisely how a more "open and participatory" society could contribute positively to development remains a research problem, in the brave new world intangibles or what Singapore leaders called "heartware" would be a key differentiator - tacit qualities that are not easily replicable. Tolerance for a more participative and pluralistic society will go some way in creating greater latitude for creativity and in encouraging an innovative society. It would be interesting how such acts of contrivance in promoting a more inclusive society as part of a greater strategic plot for economic renewal would unravel.

\section{The Setting: The Singapore 21 and the Remaking of Singapore}

Singapore 21 (S21) was mooted in 1997 with the document released in 1999. Three years after S21 was released the government introduced the Remaking of Singapore document. The two documents came during one of the most critical juncture of Singapore development. It came at a time when the Singapore economy was severely tested as a result of the Asian Financial Crisis, the dot com bubble burst in 2000 and the bombing of the WTO in New York.

\subsection{Singapore 21}

The Singapore 21 is a document that attempts to forge a new contract between the government and the governed and identify core values that will make Singaporeans feel rooted to Singapore and at the same time take in shocks that come with an increasingly uncertain world. The document was released in April 1999 and at the launch of S21, Singapore's then Prime Minister Goh Chok Tong described S21 as an attempt to strengthen the "heartware" of Singapore. That "heartware" refers to the intangibles of "social cohesion, political stability, and the collective will, values, and attitudes of a people." (Note 12)

The final document was the input of five committees made up 83 members of the public that included members of parliaments, unionists, teachers, welfare organizations etc. In all 6,000 members of the public were interviewed. Five themes or dilemmas were put forward for discussions. (Note 13) In the final report, five core themes are identified as values or vision that Singapore and Singaporeans should adopt: That Every Singaporeans Matters; Strong Families; Opportunities For All; The Singapore heartbeat and Active Citizenship.

Of special relevance is the S21 idea on Active Citizenship and the Singapore Heartbeat, two values concerned with harnessing public participation. The Singapore heartbeat describes the need to be emotionally bonded to Singapore and through active citizenship the document penned the need for Singaporeans to be involved and to take the lead in civic and community affairs. It outlines the need for Singaporeans to become "participants not mere observers (and) to learn not only to express their views or suggest alternative solutions, but also to put suggestions into action." (Note 14)The document also highlights the need to overcome social and political apathy among Singaporeans citing the need to take ownership of issues of national concerns.

An interesting highlight of the document is the need to go beyond economic imperatives. The document challenges popular perception of Singapore's development; that of a single minded pursuit of a ruling elite inclined at economic survival. The document promotes the message that nationhood and resilience in weathering a crisis comes from paying important attention at values other than just economic tangibles.

Another interesting point of the document is the use of "civic" as opposed to "civil" participation. The "Civic" Society as one understands it emphasises the "civic" responsibilities of citizens. "Civil" Society in contrast refers to the "right" of citizens. Some observers see this as more than just an exercise in semantics, a carefully chosen attempt to remove links with the potentially destabilising "politicking" practices of a civil society (Lee, 2001). "Civic" participation gave the impression of an exercise that is geared towards enhancing existing societal and institutional arrangements shaped by the ruling elite.

\subsection{Remaking of Singapore}

The Remaking of Singapore document was a supplement to the set of recommendations put forward by the Singapore Economic Review Committee; a committee tasked in December 2001, to chart Singapore's future development blueprint. Remaking of Singapore was seen as necessary, at a time when the Singapore economy was facing slow growth brought on by the dotcom bubble burst and uncertainties in the global economy as a result of the September 11 bombing of the World Trade Organisation. There was also the serious concern to engineer novel ways of sprucing 
Singapore's relevance in the marketplace given intensifying regional and global competition. The Remaking of Singapore committee was tasked to look beyond Singapore's tried and tested methods come up with new ways at making social, political and economic changes. It is fitting that the committees tasked to bring these new initiatives took inspiration from Singapore's or Singaporeans celebrated acronym the 5 "C"s but with a twist. The committees are named Beyond Condominiums, Beyond Credit Card, Beyond Cars, Beyond Country Clubs and Beyond Cash. In all, 70 recommendations were put up by the committees. More than 80 percent of the recommendations were adopted with about 11 recommendations not accepted completely or partially.

As far as participation and active citizenship is concerned, The Remaking of Singapore document is not far off from the spirit of participation espoused in the Singapore 21 document. Both documents underline the need to provide participatory space and encouraging diversity of views. In its report, the Remaking of Singapore Committee emphasized the need for Singapore "to change, to adapt and to renew" and the committee foresee that the new Singapore "will be anchored on common spaces and shared values... a society that will be able to embrace a variety of views and preferences...Singaporeans who are proactive in deciding what they want to achieve, how they want to live their lives and how they want to contribute to the community." (Note 15The Singapore 21 document also expressed the need for Singaporeans to partake in alternative solutions and to become engaged and involved in issues. The document reiterates the point that active involvement enhances ownership, passion and commitment. (Note 16)

As far as participation is concerned, both documents reflect an inspiring sea change as far as active citizenship and public participation are concerned; a message about accommodating differing viewpoints. Goh Chok Tong described the Remaking of Singapore as one "about embracing diversity... about a home where we accept each other even if we disagree from time to time...Singapore's political and social climate needs to give space for more ventilation and variation...enriching our diversity quotient... There comes a point where you must take the risk and let go, in order for your child to grow and learn...” (Goh Chok Tong, 2003).

Promising though the statements are, in the same speech, Goh puts up a cautionary note, stressing that the "new openness will be within the parameter that the government decides". Giving the anology that the government will make the golf course friendlier he says

"we will widen the fairway for discussion...But as all golfers know, every golf course has roughs, sand bunkers, water, trees and other hazards, even courses which are friendly and have no OB markers. The golfers know where the hazards are and avoid them...Singapore golf course is not new....and getting into one of these hazards does not mean getting into trouble...Many a golfer has gotten out of roughs and sand bunkers without losing a stroke (Goh Chok Tong, 2003.).

Goh also underlines the PAP government oft said policy stance that when it comes to decision that goes against public opinion the government must persuade the people that on " matters of grave national importance, where it has to lead, or act without the benefit of consulting, it must explain its position (Ibid.).

Also, on closer examination of the set of recommendations that were put forward by the Remaking of Singapore's various committees, most recommendations that were accepted were those of social importance, less demanding and test little of the PAP government's new appetite for more pluralistic viewpoints. Some of these issues include recommending that the Ministry of Education play an active role in special education, encouraging philantrophy, removing female quota for medical faculty at public universities, implementing a 5 day work week and making Singapore a hub for international events. In contrast, when it comes to weighty issues that have political ramifications, the decision was less easy. For instance, on the issue of defining "political" out of bound markers, the recommendation was not accepted, with a note stating that the reason was explained by Lee Hsien Loong in his speech at the Harvard Club Dinner. On that occasion, Lee mentioned that defining the out of bound markers would be difficult and undesirable. "Had we predefined all the parameters for discussion, civil society would have lost the spark and autonomy that allows fresh areas to be explored, limits to be redefined, and both the government and civic groups to develop a certain responsiveness to each other and move society forward by engaging each other" (Lee Hsien Loong, 2004).

Even though critics have side swiped the significance of the two documents as propaganda to regain voters confidence, one can also view the two documents as a strategic initiative that reflects the PAP government urgency to look beyond the tried and tested; an attempt by the PAP government to attenuate past policies to accommodate new societal expectations. Still, as the examples involving the Integrated Resort and Ministerial Pay would suggest, the efforts are incremental at best.

\section{The Ministerial Pay}

Back in 1994 when the Singapore leadership raised the issue of paying top dollars for its ministers, it was greeted with much rancour from the public. No surprise that when the Singapore government announced an increase ministerial pay and top civil servants in April 2007 there were no less dissenting voices. 
Pegging the ministerial pay to the private sector wage was introduced in 1994. The rationale put forward then was that the government was losing its best and capable leaders to the private sector. There is also the firm belief that paying administrators well would ensure the incorruptibility of the civil service and the continued credibility and effectiveness of the public service delivery system. Under the initiative, salaries of ministers and top civil servants are benchmarked to $2 / 3$ of the median of Singapore's top earners from six professions. Using this criterion, the median pay in 2007 should be around \$2.2 million Singapore dollars and the concern is that Singapore's ministers pay, on average, lagged this median by 55 percent. With the new revision, ministers would get an average of \$1.9 million Singapore dollars or about US\$1.26 million by the year 2008. With the increase, Singapore's Prime Minister Lee Hsien Loong earns S\$3.1 million Singapore dollars, almost 5 times what the US president George W. Bush earns and almost 8 times what former Japanese Prime Minister, Shinzo Abe gets annually.

Given the comparison, it is no surprise that public opinion against the pay hike came from many quarters. On an online petition some 2,000 signed against the pay increase. Others questioned the timing of the increase, coming at a time when the government recently announced a hike in Goods and Services Tax plus increasing concern on Singapore's growing income gap. Others questioned the methodology used in coming up with the benchmark. Even though the Singaporean public agree that ministers should be paid accordingly, the methodology adopted by the government was debatable, one in which the public wanted further deliberations. (Note 17) Others argue on the basis of moral authority and the need to keep ministers pay in perspective, with some suggesting that it has created a perception that serving the country is another financial transaction and devoid of altruistic and patriotic fervour. (Note 18) PAP Member of Parliament Denise Phua noted the danger of money and power nexus creeping into the system. Singapore's Law Society President, Phillip Jeyaratnam remarked that Singapore has long since moved away from a system based on valuing the contribution made and honouring the office for itself" by "shifting from an attempt to reward contribution to government and country to an attempt to estimate what he or she would otherwise have earned in the private sector". (Note 19) There was more activist move. The Singapore Democratic Party (SDP) tried to organize a public forum addressing the pay hike issue by inviting some foreign delegates - the Alliance of Liberals and Democrats for Europe and the Council of Asian Liberals and Democrats. The application was turned down. The foreign speakers were denied professional visit pass and to speak at the forum with the government highlighting the point that Singapore politics are reserved for Singaporeans. (Note 20)

Despite strong public arguments, in the end it was persuasion on the part of the government that tilted the argument towards accepting the government proposal. As in past policy justification, persuasion took the form of the importance of survival. Economic imperative was put across as the raison d'etre for going ahead with the proposal. In his speech, Lee Hsien Loong rebutted arguments raised during the two day parliamentary debates, arguing that not going ahead with the proposals would impact Singapore's long term survival, giving examples of other states attempt at development and the consequences for not paying top dollars for leaders. Lee Kuan Yew called the debates an absurdity and urged for a sense of proportion. Given that the annual wage bill for ministers and all office holders is \$46 million - or just 0.022 per cent of Singapore's total economic output, he said it was absurd that 'We are quarrelling about whether we should pay them \$46 million or \$36 million, or better still, \$26 million. So you save \$20 million and jeopardise an economy of $\$ 210$ billion". (Note 21 )

The issue also provided an insight into the Singapore government's policy decision making process. The idea of a possible pay hike for was first floated by Goh Chok Tong in November 2006 during a visit to Europe, though he remarked that the pay quantum and timing would be left to the Prime Minister. Given the meticulousness of the Singapore government's decision machinery, it would not be far fetched to postulate that such statement was meant to lay initial government expectations and to put out feelers to sense whether the ground was sweet for such a move. It was only on the $22^{\text {nd }}$ of March 2007 and just after the announcement of the state budget, did Prime Minister Lee Hsien Loong announce the proposal. Public discussions were then allowed for just two weeks, with government leaders intermittently making the case for the pay hike that helped in goading public opinion on how the government would eventually decide. From the debates and public opinion, the main discussion was drawn. Ultimately, issues of strategic concern, survival - especially economic survival - was usually given as a raison d'etre for such policy decisions. The line of reasoning is somewhat similar, when one discusses the issue of the Integrated Resort to be described below.

\section{Singapore Integrated Resort}

If there is any major recent issue that could gauge Singapore's commitment to active citizenship and greater level of public participation, the proposal to build an integrated resort or casino could be it.

Having a casino in the city state was first floated nearly forty years ago, when Singapore Tourism Board suggested the idea of having a gaming facility in one of the outlying islands. Then Prime Minister, Lee Kuan Yew rejected the idea citing the undesirable social consequences that comes from having a casino. But the idea resurfaced in March 2004 when Singapore's Minister of Trade and Industry George Yeo reintroduced the possibility of having a casino. 
The proposal to have a casino came out from the set of recommendations put forth by the Singapore Economic Review, tasked to look at new ways at diversifying Singapore's economic base. One of the key sectors identified by the committee is tourism. (Note 22)Even though one may claim that the drop in tourism receipts could be attributed to the spate of economic turmoil enveloping East and Southeast Asia, Singapore's share of Asia Pacific tourism market shrank from 8 percent in 1998 to 6 percent in 2002. The Singapore government feels that having a casino would provide a more sustainable tourism industry. It will also give the economy a leg up at a time when regional countries were also tinkering on establishing and expanding existing gaming facilities given the demands from Asia's new rich, especially China's nouveau riche. On government estimates, the casino project would add some $\$ 5$ billion in investment create 35,000 jobs and add 1 to 2 percent to GDP or about $\$ 1.5$ billion annually. With the completion of the two planned casinos, Singapore also expects receipts from tourism to be in the range of $\$ 30$ billion by 2015 .

Naturally, the proposal drew multitude of responses. For those against the idea, the arguments centered on social and religious grounds; that having a casino will be socially regressive with possible long term social consequences. Leaders of the Catholic Church, The National Council of Christian Churches and Muslim Groups were against the idea of gambling on religious and social grounds. A spokesman for Families against the Casino Threat in Singapore remarked that "We say one thing and do another. We tell our children that gambling is bad, but how are we to answer them when they ask why a casino is allowed in Singapore? (Note 23)There are those who questioned whether the Integrated Resort (IR) would bring economic rewards to those that need it most. Critics feel that the proposal could possibly be a knee jerk reaction to an economy that is seeing some tough times and believe that there are more creative ways at remaking Singapore and its economy. The PAP members of parliament were also evidently split on the issue. A PAP member of Parliament, Loh Meng See criticized the way society was being asked to pay in human suffering for economic gains. (Note 24)Another PAP member of parliament Tan Soo Khoon hoped that the government had picked out "the right card from the deck" saying that there are social costs that comes with economic benefits. (Note 25)

In the end, again it was persuasion PAP style that tipped public discussion and acceptance into having a gaming facility. In shifting the grounds towards adopting the proposal, persuasion took on the argument of economic survival. PM Lee Hsien Loong mentioned that it was hard to change policies that are still working, but "it is the government's responsibility to look ahead, anticipate problems and persuade people to support a necessary change. (Note 26) Lee also mentioned the spill over effects from the two Integrated Resorts and the long term effects those developments might have in the Remaking of Singapore and turning it into a vibrant city. Lim Boon Heng, Singapore's Labour chief and Minister of State also reiterated the survival message, saying that 'If not for the unemployment problem we face, I would have maintained 'no' to the casino." (Note 27) Lee Kuan Yew in his defense for the proposed project remarked that "I have not changed my values but I have had to change my attitude to a casino." (Note 28) Lee also added to the persuasion that the 'old model' he adopted in creating a first world state in a third world region is valuable but not sufficient in turning Singapore into a first rate world city that professionals seek. (Note 29) He further remarked that "if I were the prime minister and was challenged ... and I was younger man with lots of energy...I will convince Singapore that this is right - that the price is high, but the price of not doing it is even higher" (Note 30)

\section{Participation: Substance and Form}

For a start, participation on policy issues are more pronounced and tolerated. There is a greater level of public participation judging from public comments in the conventional media and the increase use of blogsites and websites. The two policies also highlighted more varied views from members of parliament within the PAP ranks. Tan Soo Khoon, a vocal commentator of policy from within the PAP rank, remarked that one potential winner from the Intergrated Resort debate is a greater level of participation. But he quickly added that it could be sustained only if the government continues allowing openness of discussion on other issues. (Note 31)

The case of the Ministerial pay hike however suggests that public debate and participation remains highly selective. The public debate on the integrated resort that lasted almost year is more of an anomaly. Perhaps in the case of the Integrated Resort, more protracted discussions were allowed given the sensitivity of the issue and the Singapore leadership long standing aversion for a casino, especially Lee Kuan Yew after his initial rejection of the idea nearly forty years ago. To the government's credit, initiatives proposed by the public were incorporated in the final adoption of the policy; enacting the Casino Control Bill and establishing the National Council on Problem Gambling. In contrast, discussions on the Ministerial Pay were less protracted. Even though Singapore Senior Minister Goh Chok Tong hinted on the impending pay revision in November 2006, the proposal was formally announced only in March the $22^{\text {nd }}$. Unlike the Integrated Resort issue, public debate was kept to only two weeks. Public discussions, especially issues on benchmarking methodology, made little or no impact on the final decision other than portray to the public that a fair amount of discussion was allowed. The ban on foreign delegates to discuss on the issue also underlined PAP's assertion of where the political out of bounds markers should be.

Although it would be administratively paralyzing to allow every policy issue to be debated for a year as in the case of the Integrated Resort, the case of the ministerial pay suggests that permitting public participation depends on the 
severity such issues can impinge on the ruler -ruled nexus. Prolonged debate on the ministerial issue could potentially be socially divisive especially at a time, when there was growing concern of rich poor divide. Decision had to be swiftly executed, public discussions kept to a minimum and decisions executed persuasively. In fact, in his defence of the Integrated Resort, Lee Hsien Loong hinted at the PAP government's usual decision making operandi. Lee remarked that the public discussion on the Integrated Resort was an exception, a first, as the PAP led government usually avoids agonizing over policies in public and that its usual approach would be to settle the main lines of policy, then explain it to the public to reduce confusion." (Note 32)

The policy execution on the IR and the ministerial pay also suggest that participation, Singapore style, is one of pseudo or partial in character. There is a sense of inevitability - at least among the public - that no matter how intense public debate would be, the government would go ahead with its initial proposal. Juxtaposing Pateman's (1970) description, public participation is just a technique to persuade the public to accept the decisions that have already been made. In fact, PAP Member of Parliament, Tan Soo Khoon, went as far as suggesting that the decision to go ahead with the Integrated Resort is one of "Singapore's worst kept secret", suggesting in effect the inevitability of the outcome regardless of the weight of debates against the idea. (Note 33)It impresses the point that public discussion was held just to create a sense of participation and that ultimate power to decide rests on the elite few in government through persuasion. In this case, persuasion, Singapore style, takes on the arguments of the need to maintain Singapore's competitive edge, highlighting Singapore's inherent vulnerabilities and the high cost of policy inaction to Singapore's survival etc.

The case of Singapore also highlighted the importance of authority, structure and norms in state's provision of public participation. The arguments by Eckstein (1966), Dahl (1956) and Berelson (1952) prove that participation and decision making is not totally devoid of the political, social and economic complexities of the society. Society is socialized into accepting an indigenous form of authority and the examples of the Integrated Resort and the Ministerial Pay suggest that Singapore's leadership understand that its application of authority to go ahead with the two proposals was congruent to the "authority level acceptable" by the larger society. Forty eight years of uninterrupted PAP rule has socialized the Singaporean society into accepting a form of authority that inadvertently affects the tenor of public debates. Public discussions on the Ministerial pay for instance, brought home the point that the Singapore society largely "accepts" the leadership's argument (authority). Even though the point of contention was on the best form of remuneration, the main thrust of the government's argument that ministers should be "appropriately" paid was largely agreed on. To a large majority of the citizenry, ministers should be paid accordingly in order to sustain and improve current delivery system. The sense of inevitability of outcome is also evident on the issue of the Integrated Resort. The year- long debate on the casino portrayed an inevitable outcome with statements by ministers and debates by the media creating the momentum and forming public opinion into accepting the proposal. In fact, leading up to the final announcement on the Integrated Resort, public opinion was not about whether there will be a casino but rather the number of casinos that would be allowed.

But society's "acceptable" level of authority is a dynamic process and very much a function of social and economic change. So far the PAP led state has been successful in devising ways in managing changing societal expectations, in large measures through creating new institutions in accommodating Singapore society's changing appetite on the "accepted" level of authority. For Singapore, state designed institutions - rather than that arising from civil society - are used to accommodate the growing need for more public involvement. In fact, there were occasions when civil society groups or NGO's are brought into state designed institutions. Singapore's Nominated Member of Parliament (NMPs) for instance at times comprised of members of Women Group (AWARE) or independent think tank (the Roundtable Group), an incisive move at bringing alternative voice into state designed institutions.

However present boundaries of public participation will continually be tested and the state must keep up with creative ways at managing these changing expectations. So far there is little distinction between the Remaking of Singapore document from earlier documents like the Singapore 21 and the White Paper on Shared Values, as far as addressing the need for active citizenship, inclusiveness and participation are concerned. These values are embodied in various degrees in the three documents. The state must design new ways other that coming up with new documents with similar underpinnings. These documents could temporarily assuage society's greater appetite for participation, but it may not eliminate the form-substance deficit.

That task to come up with creative ways of managing expectations would be increasingly challenging for the PAP leadership. Changing demographics, growing income gap, an increasingly mobile and well informed younger population plus an increasing number of naturalized citizens socialized with a different attitude to forms of authority, would require a new approach and a break from past policy remedies. Expanding the PAP state institutions and making further inroads into Singapore's political space would be increasingly tenuous given society's complexity. Issues of political out of bound markers, increasing use of cyberspace as a form of participation and the impact of new citizens to its political, economic and social structures will increasing test the PAP leadership as far as creating more participatory 
space. In short, the PAP current strategy of expanding state institutions and stymieing the growth of civil society must constantly be held up against the Singapore's society changing acceptance level of authority brought on by a greater need for policy ownership.

Failure to manage changing expectations and to continue employing the archetype policy justification could possible generate what one prominent Singapore writer, Catherine Lim describes as the "great affective divide" - an estrangement between the government and the governed. Lim (2007) wrote that employing the tried and tested policy execution would do "away altogether with the compact of trust and respect". She went on to reiterate that it would create a "new affective" divide or reinforce existing one that will reduce the relationship between the government and the people to a purely business contract. Lim believes that the debates and the final position of the Singapore government on the issue of the ministerial pay could entrench political apathy, creating a possible disconnect between the ruler and the ruled.

"(It) will breed weary resignation in Singaporeans: What's the use of giving one's view at all? And, at worst, give rise to toxic cynicism: What's the use of teaching our young such values as caring and selflessness and sacrifice if each carries a price tag." (Lim, 2007).

\section{Conclusion}

The examples on the Integrated Resort and the Ministerial Pay demonstrate that state's role in encouraging public participation is bounded by a preset of institutional structures carved out from the PAP idiosyncratic leadership qualities and Singapore's unique political economy. As much as the PAP led government wants to encourage active citizenship and greater participation, the example of the Integrated Resort and Ministerial Pay suggest that it will be incremental in nature. The PAP 48 years of uninterrupted leadership will make it difficult for the party to abandon its preset of authority structures and norms; structures and norms that the party sees as instrumental to Singapore's phenomenal growth. This is demonstrated when public need for participation is accommodated in so far as through generating the "feeling" that the state is willing to allow participation, much akin to Pateman's (1970) description of partial or pseudo participation. The two documents (S21 and Remaking of Singapore) may demonstrate the government's willingness to allow public participation on issues of national concerns but the Ministerial Pay and the Integrated Resort issues demonstrated little radical departure in the PAP decision making modus operandi.

The experience of Singapore underlines the point that participation cannot be divorced from society's inherent authority structures. Level of participation and acceptance to authority are societal idiosyncrasies and it will be interesting how the PAP regime will continue to match its own authority structures and norms to that of the larger society. Going forward, it might prove inevitable that the PAP led government would have to look at more sophisticated ways in accommodating society's greater appetite for participation; more than just having another new document. It involves the regime to question the assumptions of its existing authority structure and whether those assumptions remain valid.

Public participation is an important element in strengthening the social fabric. Although in the Singapore case, one may argue that enlarging state institutions into the larger political space has worked in assuaging the need for participation, Singapore's social fabric could be seriously tested during moments of economic adversity. Such events will demand societal resilience - a quality that could be tapped from having greater level of participation, stronger sense of ownership and a healthy civil society.

\section{References}

Austin I. (2001). Pragmatism and public policy in East Asia: origins, adaptations and developments. Singapore: Fairmount International.

Barnes M., N. Marian and H. Sullivan (2004). Power, participation and political renewal. Journal of Social Politics, 11(2).pp 267-279

Berelson.B.R. (1952). Democratic theory and public opinion. Public Opinion Quarterly, 16( 3). pp313-330

Business Times (2005). All eyes on government's casino decision, April 18.

Chan H.C. (1975). Politics in an administrative state: where has the politics gone? In Seah, C.M.(Ed.) Trends in Singapore. Singapore: Institute of Southeast Asian Studies.

Dahl, R.A.(1956). Preface to democratic theory. Chicago: University of Chicago Press.

Dahl, R.A (1966). Further reflections on the elitist theory of democracy. American Political Science Review, 60(2) pp 296-305.

Eckstein. H (1966). A theory of stable democracy. Princeton: Princeton University Press.

Financial Times (2006). Why inequality is center stage in Singapore's election? May $4^{\text {th. }}$ 
Goh Chok Tong (2003). Speech by Prime Minister Goh Chok Tong at the Remaking Singapore Report presentation and appreciation lunch on Saturday, 12 July 2003.

Jong S. Jun (Ed.) (1994), Development in the Asia Pacific. New York: Walter de Gruyter.

Jon ST. Quah (2000). Political consequences of rapid economic development in Singapore, in Jong S. Jun (Ed) (1994). Development in the Asia Pacific. New York. Walter de Gruyter.

Koh, Gillian (1998), Bureaucratic rationality in an evolving developmentalist state: the case of Singapore. In Gambhir Bhatta and Joaquin L. Gonzalez III (Eds.) Governance innovations in the Asia Pacific region: trends, cases and issues. Aldershot: Ashgate.

Lee Hsien Loong (2004). Let's shape our future together. Swearing in speech delivered at the Istana, 12 August 2004. Lee Hsien Loong (2004). Speech at the Harvard Club. 6 Jan 2004.

Lee, Terence (2001). The State of Civil Society in Singapore. Media Development

Lee, Terence (2005). Gestural politics: civil society in "new" Singapore. Sojourn: Journal of Social Issues in Southeast Asia, 20 (2). Pp132-154

Mansfield J. (1995). Does participation make better citizens? , Paper delivered at the Political Economy Good Society Conference, Feb 11-12, 1995.

Mcgregor, D (1960). The human side of enterprise. McGraw Hill: New York.

Mill, J.S. (1964). Utilitarianism, liberty and representative government. London: Dent.

Milne, R.S. \& Mauzy, Diane K. (2002). Singapore politics under the People's Action Party. London and New York: Routledge.

Pateman, Carole (1970). Participation and democratic theory. Cambridge: Cambridge University Press.

Remaking of Singapore Report.

Rodan, Gary (2006). Singapore “exceptionalism”? authoritarian rule and state transformation. Working Paper No. 131, Asia Research Centre, Murdoch University.

Rousseau. J.J. (1968). The Social Contract. London: Penguin Books.

Schumpeter, Joseph (1942). Capitalism, Socialism and Democracy. New York: Harper \& Brothers.

Singapore 21 Report

Straits Times (1989).

Straits Times (2006). Net was abuzz with politics. May $9^{\text {th }}$.

Straits Times (2006). Regrouping the Singapore diaspora. September $30^{\text {th. }}$

Straits Times (2007). NZ govt took heed of public views in setting pay. March 27.

Straits Times (2007). Top lawyer weighs in on salary debate. June 2.

Straits Times (2007). Government says no to SDP public forum, bars foreign speakers. April 13.

Straits Times (2007). Put ministers' pay in perspective: MM. April 5.

Straits Times (2005). The old virtues are valuable but no longer sufficient. April 20.

Straits Times (2005). PM Lee rallies Singaporeans. April 22.

Straits Times (2005). Unconvinced MPs worry about social ills; fallout from addiction, effects on work ethic among concerns. April 20.

Straits Times (2005). What will Singapore be like post 2009? Straits Times Forum. April 22.

Straits Times (2005). PM confident most Singaporeans back idea. April 22, 2005.

Straits Times (2005). Labour Chief: I could not say no to 35,000 jobs. April 20.

Straits Times (2005). The old virtues are valuable but no longer sufficient. April 20.

Straits Times (2005). Unconvinced MPs worry about social ills. April 20.

Straits Times (2007). Be mindful of the affective gap. April 5.

Straits Times (2007). Lee Hsien Loong: excerpts of parliamentary speech. April 22.

Verba, S.(1961). Small Groups and Political Behaviour. Princeton:Princeton University Press. 


\section{Notes}

Note 1. In Pateman's (1970) describes that "the concern was not to set up a situation where participation (in decision making) took place, but to create a feeling of participation through the adoption by the leader (supervisor) of a certain approach or style; 'participation' was thus 'limited to member endorsements of decision made by the leader who....is neither selected by the group for his actions...the group leader, has a particular goal in mind and uses the group discussion as a means of inducing acceptance of the goal.” p. 69.

Note 2. Net was Abuzz with Politics during Poll Period. The Straits imes. May 9, 2006.

Note 3. Ibid.

Note 4. The election result in 2006 saw the ruling PAP share of votes dropped to 66.6 percent from a high of 75 percent from the previous election in 2001.

Note 5. Why inequality is centre stage in Singapore's election, Financial Times, May 4, 2006.

Note 6. In the Agenda for Action, the government formed six advisory councils in the area of culture and the arts, sports and recreation, family and community life, youth, the handicapped, and the aged, each headed by a cabinet minister in Quah, 1989:2 in Jon ST Quah political consequences of Rapid Economic Development in Singapore p43.

Note 7. Ibid.

Note 8. Straits Times, July 25, 1984 from Jon S.T. Quah, Political Consequence of Rapid Economic Development in Singapore).

Note 9. Straits Times, November 30, 1989.

Note 10. The five values outlined by the white paper on Share Values include; Nation before community and society before self; family as the basic unit of society; community support and respect for the individual; consensus not conflict and racial and religious harmony.

Note 11. Regrouping the Singapore Diaspora, The Straits Times September 30 2006.

Note 12. Singapore 21 Report p2.

Note 13. The five dilemmas include: between less stressful life vs retaining the drive; needs of senior citizens vs aspiration of the young; Attracting talent vs looking after Singaporeans; internationalization/regionalization vs Singapore as how; consultation and consensus vs decisiveness and quick action.

Note 14. The Singapore 21, Together We Make a Difference. Since its introduction the Singapore 21 document has been adopted by the civil service and public organisation. The Civil Service for instance has adopted the Public Service 21 document, charting new values needed by the civil service. Also there is the Retail 21 which is a 10 year strategic plan for growth in the retail sector and the Manpower 21 that sets out a blueprint to address issues of manpower development, manpower planning. Life long learning and there are others.

Note 15. Remaking of Singapore document pp 5-6

Note 16. Singapore 21 document $\mathrm{p} 14$

Note 17. Others questioned the benchmarking measurement put up by the government, suggesting that the government takes instead a moving average or perhaps benchmarking againsts leaders of the G8.

Note 18. March 27, NZ govt took heed of public views in setting pay, the Straits Times.

Note 19. Top Lawyer Weighs in on Salary Debate, Straits Times, June 2, 2007.

Note 20. Government Says No to SDP Public Forum, Bars Foreign Speakers. Straits Times. April 13, 2007

Note 21. Straits Times, Put ministers' pay in perspective: MM, April 5, 2007.

Note 22. MTI Budget speech 2004, quoted in Business Times, All Eyes on Government's Casino Decision, April 18, 2005 Monday.

Note 23. One wrote to Singapore's Straits Time Forum page, saying that having a casino will not help those who are most in need. The additional employment he says will be in the form of low paying jobs and that his take on cities with casino were pretty dismal "littered with broken homes, pawnshops and the homeless. In the Straits Times, What will Singapore be like Post 2009? Straits Times Forum, April 22

Note 24. Straits Times, April 22, 2005, PM Lee rallies Singaporeans; Move on, close ranks and make integrated resorts with casinos work, he says. Lydia Lim, Senior Political Correspondent

Note 25. Straits Times Unconvinced MPs worry about social ills; Fallout from addiction, effects on work ethic among concerns, April 20, 2005. 
Note 26. quoted in the Straits Times, PM Confident most Singaporeans back idea, April 22, 2005

Note 27. Straits Times. Labour Chief: I could not say no to 35,000 jobs, April 20, 2005

Note 28. Straits Times, The old virtues are valuable but no longer sufficient. April 20, 2005

Note 29. MM Lee backs decision on resorts with casinos; The old virtues are valuable but no longer sufficient, Straits Times, April 20, 2005).

Note 30. Ibid.

Note 31. Straits Times, Unconvinced MPs worry about social ills”, Straits Times April 20, 2005, Wednesday.

Note 32. Lee Hsien Loong: Excerpts of Parliamentary Speech. April 22, Straits Times.

Note 33. Straits Times, Unconvinced MPs worry about social ills”, Straits Times April 20, 2005, Wednesday. 